\title{
Gambaran Tingkat Pengetahuan Mengenai Stroke pada Keluarga Pasien Pasca Stroke dengan Serangan Terakhir Kurang dari Satu Tahun: Literature Review
}

\author{
Septeana Tria Adin Adila ${ }^{1}$, Fitria Handayani ${ }^{1 *}$ \\ ${ }^{1}$ Departemen Ilmu Keperawatan Fakultas Kedokteran Universitas Diponegoro, Semarang, Indonesia \\ fitria.handayani@fk.undip.ac.id
}

\begin{abstract}
Introduction: Stroke patients rely heavily on family on decision-making for health actions should be done. The family members were found to have attitudes that are not right in doing in-home care for it is associated with knowledge of family low. On other side, the family knowledge level would lead in readiness of taking care of family members suffering from stroke with better. Based on the variation of knowledge level and influence, the researchers are interested to do literature review regarding the level of stroke knowledge on the patients families after the stroke last less than 1 year.

Methods: The study aimed to review stroke knowledge level on the patients families after the stroke last attack less than 1 year. This study was a literature review conducted based on the issue, methodology, similarities and proposal advanced research. Search articles used EBSCO, google scholar, SINTA (Science and Technology Index), science direct, clinical key, and Scopus with the publication of the last 5-10 years.

Results: The result showed that level of knowledge of post-stroke patients families with the last attacked less than a year from the ten articles that have been analyzed, 6 articles majority was still low with the range 63,8\%-100\% and 4 articles was high knowledge with the range 58\%-74\%. The majority low level of knowledge 3 articles was from India. Factors that affect the level of family knowledge about stroke were the education provision, education level and age.

Conclusion: The stroke knowledge level in patients families post-stroke with the attacks last less than 1 year, the majority still in the low category so that expected health workers especially the nurses in giving health education on patients and families.
\end{abstract}

Keywords: Stroke Knowledge, Family, One Year.

\begin{abstract}
Abstrak
Pendahuluan: Pasien stroke sangat bergantung pada keluarga mengenai pengambilan keputusan untuk tindakan kesehatan yang dilakukan. Beberapa anggota keluarga memiliki sikap tidak tepat dalam melakukan perawatan di rumah. Hal itu berhubungan dengan rendahnya pengetahuan keluarga. Sebaliknya, tingginya pengetahuan keluarga akan mengarah dalam kesiapan merawat anggota keluarga pasca stroke dengan baik. Berdasarkan variasi tingkat pengetahuan dan pengaruhnya, maka peneliti tertarik melakukan literature review mengenai tingkat pengetahuan stroke pada keluarga pasien pasca stroke dengan serangan kurang dari satu tahun. Tujuan penelitian ini adalah menelaah tingkat pengetahuan mengenai stroke pada keluarga pasien pasca stroke dengan serangan terakhir kurang dari satu tahun.

Metode: Penelitian ini menggunakan literature review yang dilakukan issue metodologi, persamaan dan penelitian mutakhir. Pencarian artikel menggunakan EBSCO, google scholar, SINTA (Science and Technology Index), science direct, clinical key, dan scopus dengan publikasi 5-10 tahun terakhir dan dapat diakses fulltext untuk menemukan artikel sesuai kriteria inklusi.
\end{abstract}


Hasil: Hasil penelitian ini menunjukkan bahwa tingkat pengetahuan keluarga pasien pasca stroke dengan serangan terakhir kurang dari satu tahun dari sepuluh artikel penelitian diperoleh mayoritas tingkat pengetahuan keluarga masih rendah (63,8\%-100\%), mayoritas tingkat pengetahuan tinggi (58\%-74\%). Mayoritas tingkat pengetahuan pengetahuan rendah dari India. Faktor yang mempengaruhi tingkat pengetahuan keluarga mengenai stroke sesuai dengan sepuluh artikel yang dianalisis adalah pemberian edukasi, tingkat pendidikan dan usia.

Kesimpulan: Tingkat pengetahuan stroke pada keluarga pasien pasca stroke mayoritas masih dalam kategori rendah sehingga diharapkan tenaga kesehatan khusunya perawat lebih maksimal dalam memberikan pendidikan kesehatan pada pasien maupun keluarga.

Kata Kunci: Pengetahuan Stroke, Keluarga, Satu Tahun

\section{PENDAHULUAN}

Stroke merupakan keadaan dimana terputusnya aliran darah menuju otak, hal ini secara umum terjadi akibat pecah atau tersumbatnya pembuluh darah ke otak sehingga berkurangnya pasokan nutrisi dan oksigen ke otak (World Health Organization, 2014). Berkurangnya pasokan nutrisi dan oksigen ke otak dapat menyebabkan terjadinya gangguan fisik atau disabilitas. Menurut data yang didapat dari WHO tahun 2016, stroke menjadi penyakit pembunuh kedua setelah penyakit jantung iskemik. Terdapat peningkatan penderita stroke di Indonesia dari tahun 2013 yang berjumlah 7 per 1000 penduduk menjadi 10,9 per 1000 di tahun 2018 (Kementerian Kesehatan Republik Indonesia, 2018). Berbagai macam dampak dapat terjadi pada pasien pasca stroke kurang dari satu tahun diantaranya berupa depresi, fatigue, penurunan fungsi motorik dan stroke berulang (Handayani \& Pudjonarko, 2015; Egerton et al., 2015).

Pasien pasca stroke sangat bergantung pada orang-orang di sekitarnya, khususnya pada keluarga yang merupakan orang terdekat. Keluarga merupakan komponen penting dalam proses pemulihan seorang pasien karena keluargalah yang paling mengetahui kondisi kesehatan pasien dan menjadi bagian penting dalam proses pemulihan atau pengendalian penyakit stroke agar tidak terjadi stroke berulang (Fadilla, 2012).

Kurangnya tingkat pengetahuan keluarga mengenai penyakit stroke akan berdampak pada keparahan penyakit pasien, terjadinya serangan ulang, kelumpuhan bahkan kematian. Oleh karena itu, pengetahuan keluarga dalam penanganan stroke di rumah sangat penting untuk memberikan perawatan yang terbaik bagi pasien pasca stroke. Pengetahuan yang kurang menyebabkan keluarga pasien terlambat dalam mencari pengobatan saat terjadi serangan, timbul depresi, keparahan penyakit pasien, terjadinya serangan ulang, kelumpuhan bahkan kematian (Zeng, et al., 2012).

Pada sebuah penelitian, beberapa anggota keluarga ditemukan memiliki sikap yang tidak tepat dalam melakukan perawatan di rumah bagi pasien pasca stroke (Haghighi, Karimi, Amiri, 2010). Suatu penelitian menyebutkan beberapa anggota keluarga pasien pasca stroke mengatakan jarang membantu pasien untuk melakukan gerakan fisik di rumah, tidak terlalu mengerti makanan seperti apa yang seharusnya dihindari, dan karena banyaknya kesibukan, keluarga terkadang lalai untuk mengantar pasien untuk kontrol ke rumah sakit. Hal itu berhubungan dengan pengetahuan keluarga yang rendah (Safitri, 2012). Sebaliknya, hasil dari sebuah penelitian menyatakan bahwa 
tingkat pengetahuan keluarga yang tinggi akan mengarah dalam kesiapan merawat anggota keluarga yang menderita stroke dengan baik. Penelitian lain menyatakan bahwa mayoritas tingkat pengetahuan keluarga pasien pasca stroke tinggi yaitu $73,8 \%$ menunjukkan bahwa keluarga pasien pasca stroke mampu memberikan dukungan yang baik berupa pemberian perawatan kepada anggota keluarga yang terkena stroke termasuk pelaksanaan program pengobatan (Allo, 2015). Hasil penelitian tentang tingkat pengetahuan keluarga pasien stroke bervariasi. Tahun pertama merupakan waktu pasien melakukan rehabilitasi secara efektif. Oleh karena itu, peneliti tertarik untuk melakukan kajian literatur (literature review) mengenai "Gambaran Tingkat Pengetahuan Mengenai Stroke pada Keluarga Pasien Pasca Stroke dengan Serangan Terakhir Kurang dari 1 Tahun"

\section{METODE}

Metode penelitian yang digunakan adalah kajian literatur (literature review). Kajian literatur ini menyajikan data univariat mengenai pengetahuan stroke yang disusun melalui penelusuran artikel penelitian yang sudah terpublikasi. Penelusuran dilakukan menggunakan EBSCO, google scholar, SINTA (Science and Technology Index), science direct, clinical key, dan scopus sesuai kata kunci yang ditentukan. Artikel penelitian yang digunakan adalah artikel dengan publikasi 5-10 tahun terakhir (2010-2020). Kata kunci dalam pencarian artikel luar negeri yaitu "stroke knowledge and family", "stroke education and family", sementara untuk artikel Indonesia menggunakan kata kunci "pengetahuan stroke dan keluarga" serta "edukasi stroke dan keluarga". Kriteria inklusi yang digunakan dalam penelitian ini adalah penelitian kuantitatif dengan responden yang merupakan keluarga sebagai caregiver berusia minimal 18 tahun dan serangan terakhir pasien stroke adalah kurang dari satu tahun. Semua data yang diperoleh dari pencarian pada database sebanyak 55.910 artikel penelitian dan dipersempit kembali dengan memilih artikel yang sesuai dengan kriteria inklusi menjadi 10 artikel. Selanjutnya peneliti melakukan analisis dan sintesis literatur menggunakan matrik sintesis. Penulis menarik kesimpulan dengan cara membaca dengan seksama informasi dari setiap artikel yang ditemukan dan menganalisis artikel tersebut.

\section{HASIL}

Terdapat 55.910 artikel yang relevan dengan kata kunci pencarian dan didapatkan 10 artikel yang memenuhi kriteria inklusi sebagai sumber data untuk direview. Proses selanjutnya dalam menyusun literature review adalah menganalisis masing-masing sumber dengan mengidentifikasi informasi penting yang terkandung didalamnya kemudian dikembangkan menjadi sebuah kesimpulan yang umum atau menyeluruh menggunakan matriks sintesis. Hasil analisis artikel diperoleh enam artikel dengan hasil mayoritas keluarga berpengetahuan rendah dengan rentang 63,8\% - 100\% (Anand, Sumet, \& George, 2017; Rachmawati, Ningsih, \& Andarini, 2020; Pandit, Mathews, Sangle, 2017; Singh \& Sandeepkumar, 2019), tingkat pengetahuan keluarga yang tinggi terdapat pada empat artikel dengan rentang 58\%74\% (Rajegowda, Pinto, \& George, 2017; Pothiban, Khampolsiri, \& Srirat, 2018; Sukron \& Putthikhanim, 2016; Semet, Kembuan, \& Karema, 2016) dan artikel dengan mayoritas pengetahuan keluarga rendah paling banyak terdapat di negara India dengan total empat penelitian. 


\section{PEMBAHASAN}

Berdasarkan 55.910 artikel yang ditemukan dan disaring berdasarkan kriteria inklusi menjadi 10 artikel, ditemukan hasil mengenai tingkat pengetahuan pada keluarga pasien pasca stroke kurang dari 1 tahun tergolong dalam kategori mayoritas tingkat pengetahuan rendah yaitu 6 artikel dengan rentang $63,8 \%$ sampai $100 \%$ (Anand, Sumeet, \& George, 2017; Cheng, Chair, \& Chau, 2018; Pandit, Mathews, \& Sangle, 2017; Rachmawati, Ningsih, \& Andarini, 2020; Saad, Waqar, Islam, Iqbal, \& Nomani, 2017; Singh \& Sandeepkumar, 2019). Terdapat empat artikel dengan tingkat pengetahuan yang tinggi dengan rentang 58\%-74\% (Pothiban, Khampolsiri, \& Srirat, 2018; Rajegowda, Pinto, \& George, 2017; Semet, Kembuan, \& Kerema, 2016; Sukron \& Phutthikhamin, 2016).

Hasil analisis artikel penelitian tersebut sesuai dengan hasil penelitian lain yaitu tingkat pengetahuan keluarga pasien pasca stroke yang rendah dengan persentase $57,4 \%$ dibanding dengan pengetahuan tinggi sebesar 42,6\% (Simandalahi, 2017). Penelitian lain juga mendukung analisis artikel ini dengan hasil tingkat pengetahuan keluarga pasien pasca stroke rendah sebesar $68,5 \%$ dibanding dengan pengetahuan cukup sebesar $31,5 \%$. Penelitian dengan hasil pengetahuan tinggi terdapat pada empat artikel yaitu artikel ketiga, keempat, kelima dan ketujuh.

Peneliti telah menganalisis faktor yang mempengaruhi tingkat pengetahuan keluarga mengenai stroke. Hasil analisis menyatakan bahwa hasil tingkat pengetahuan rendah mayoritas ada pada penelitian di Negara India dengan empat artikel. Menurut beberapa penelitian salah satu penyebab kurangnya pengetahuan di India dipengaruhi oleh pemberian edukasi dari tenaga kesehatan yang tidak optimal (Das, Mondal, Dutta \& Mukherjee, 2010; Pandian et al, 2015). Berbeda dengan penelitian di negara lain menyatakan pemberian edukasi oleh tenaga kesehatan yang optimal menghasilkan tingkat pengetahuan keluarga pasien stroke tinggi (Schneider et al., 2011). Penelitian lain juga menyatakan bahwa dengan pemberian edukasi pada keluarga yang optimal mampu meningkatkan tingkat pengetahuan keluarga pasien pasca stroke (Kosasih, Solehati, \& Isabela, 2018). Berdasarkan penelitian-penelitian tersebut peneliti menyimpulkan bahwa pemberian edukasi merupakan salah satu faktor yang mempengaruhi tingkat pengetahuan keluarga.

Pada artikel penelitian dengan kategori pengetahuan rendah, karakteristik responden masih didominasi dengan tingkat pendidikan yang rendah. Sementara pada tingkat pengetahuan yang tinggi mayoritas pendidikan responden cukup tinggi. Peneliti menyimpulkan bahwa tingkat pengetahuan keluarga dipengaruhi oleh tingkat pendidikan. Terbukti pada kategori pengetahuan baik, mayoritas responden memiliki tingkat pendidikan yang tinggi. Sementara pada kategori buruk, mayoritas responden memiliki tingkat pendidikan rendah. Hal tersebut sesuai dengan hasil penelitian pertama dimana pada artikel tersebut menyebutkan bahwa pada responden yang berpendidikan tinggi terdapat 12 responden berpengetahuan baik dan 3 responden berpengetahuan kurang, sedangkan pada responden yang berpendidikan kurang keseluruhannya yaitu 5 responden berpengetahuan buruk. Hasil analisis tersebut juga didukung oleh penelitian lain yang memiliki responden mayoritas berpendidikan tinggi maka hasil pengetahuan mengenai stroke juga tinggi (Allo, 2015).

Semua artikel hasil review menunjukan bahwa responden dengan tingkat pengetahuan tinggi memiliki usia 
yang lebih produktif dari pada responden yang masuk kategori pengetahuan rendah Anand, Sumeet, \& George, 2017; Cheng, Chair, \& Chau, 2018; Pandit, Mathews, \& Sangle, 2017; Pothiban, Khampolsiri, \& Srirat, 2018; Rachmawati, Ningsih, \& Andarini, 2020; Rajegowda, Pinto, \& George, 2017; Saad, Waqar, Islam, Iqbal, \& Nomani, 2017; Semet, Kembuan, \& Kerema, 2016; Singh \& Sandeepkumar, 2019; Sukron \& Phutthikhamin, 2016). Usia produktif merupakan usia yang mampu menghasilkan barang dan jasa dengan rentang usia 15-64 tahun (Subri, 2003). Pada kategori tingkat pengetahuan tinggi responden memiliki rentang usia dari 18-65 tahun, sementara responden dengan tingkat pengetahuan rendah memiliki rentang usia 19-80 tahun.

Penelitian lain yang memiliki responden usia $18-40$ memperoleh hasil pengetahuan yang baik (Allo, 2015). Hasil penelitian pada lainnya juga menyatakan bahwa responden dengan rentang usia 2850 tahun memiliki pengetahuan yang baik dan menyebutkan bahwa usia mempengaruhi tingkat pengetahuan mengenai stroke (Wardhani \& Martini, 2014). Berdasarkan artikel-artikel penelitian tersebut, peneliti menyimpulkan bahwa usia termasuk faktor yang mempengaruhi tingkat pendidikan keluarga pasien pasca stroke. Keluarga dengan usia yang lebih produktif cenderung memiliki pengetahuan yang tinggi.

Pengambilan data yang terdapat di artikel-artikel tersebut dilakukan di tempat yang beragam mulai dari bangsal rawat inap, rawat jalan dan di komunitas. Pada penelitian yang diambil di ruang rawat inap tiga penelitian menyatakan mayoritas pengetahuan keluarga rendah (Pothiban, Khampolsiri, \& Srirat, 2018; Semet, Kembuan, \& Kerema, 2016: Sukron \& Phutthikhamin, 2016) dan satu lainnya menyatakan mayoritas pengetahuan tinggi (Pandit, Mathews, \& Sangle, 2017).
Sementara untuk penelitian yang diambil di rawat jalan sebanyak 2 artikel tergolong kategori mayoritas pengetahuan keluarga tinggi (Anand, Sumeet, \& George, 2017: Rachmawati, Ningsih, \& Andarini, 2020) dan 1 artikel menyatakan rendah (Rajegowda, Pinto, \& George, 2017). Terdapat 1 penelitian yang mengambil data di komunitas dan hasilnya mayoritas pengetahuan keluarga tergolong tinggi Cheng, Chair, \& Chau, 2018).

Pengetahuan keluarga di rumah sakit tergolong rendah karena tenaga kesehatan termasuk perawat lebih cenderung fokus terhadap kesembuhan fisik pasien dan tidak terlalu mempedulikan pendidikan kesehatan kepada keluarga (Zeng, et al., 2012). Sementara di komunitas, keluarga akan lebih banyak mendapatkan pengetahuan baik dari tenaga kesehatan maupun dari orang-orang sekitar setelah anggota keluarganya keluar dari rumah sakit. Keluarga pasien pasca stroke yang baru keluar dari rumah sakit akan semakin sadar dan waspada terhadap perawatan pasien pasca stroke karena khawatir akan terjadi serangan ulang sehingga lebih cenderung aktif mencari informasi mengenai stroke (Hokmabadi, Vahdati, \& Rikhtegar, 2017). Oleh karena itu diharapakan perawat mampu memberikan pendidikan kesehatan secara maksimal untuk keluarga dan pasien sejak awal pasien masuk rumah sakit maupun setiap melakukan kontrol kesehatan setelah kepulangannya dari RS (Febriani, Handiyani, \& Kuntarti, 2019).

Untuk mengatasi masalah rendahnya pengetahuan pada keluarga pasien pasca stroke dapat diberikan intervensi berupa pendidikan kesehatan yang disampaikan oleh tenaga kesehatan baik dokter maupun perawat (Kosasih, Solehati, \& Isabela, 2018). Pendidikan kesehatan dapat diberikan secara lisan, audiovisual dalam bentuk video maupun melalui media cetak seperti leaflet dan booklet (Riduan, 2018; 
Lailatun, Nurwahyuni, \& Wahyuni, 2018. Pemberian intervensi berupa pendidikan kesehatan terbukti efektif dalam meningkatkan tingkat pengetahuan keluarga pasien pasca stroke (Lailatun, Nurwahyuni, \& Wahyuni, 2018).

\section{KESIMPULAN DAN SARAN}

Hasil tingkat pengetahuan keluarga pasien pasca stroke dengan serangan terakhir kurang dari satu tahun tergolong dalam tingkat pengetahuan rendah dengan total enam dari sepuluh penelitian. Mayoritas hasil penelitian dengan kategori tingkat pengetahuan rendah ada pada penelitian di India dengan total 4 artikel. Faktor yang mempengaruhi tingkat pengetahuan keluarga mengenai stroke sesuai dengan 10 artikel yang dianalisis adalah pemberian edukasi, tingkat pendidikan dan usia. Semakin optimal pemberian edukasi, semakin tinggi tingkat pendidikan dan semakin produktif usia keluarga maka semakin tinggi pengetahuan yang dimiliki. Bagi perawat ruang dengan beban kerja tinggi diharapkan tetap mengoptimalkan pemberian edukasi dengan cara lisan maupun tertulis berupa booklet, leaflet atau pemutaran video mengenai stroke melalui alat elektronik yang tersedia di RS seperti televisi. Bagi perawat di poli diharapkan juga selalu memberikan edukasi secara maksimal setiap pasien dan keluarga melakukan kontrol kesehatan berupa lisan, pemberian leaflet pada setiap pasien yang datang maupun pemasangan poster pada ruang tunggu poli. Bagi perawat komunitas diharapkan mempu memberikan edukasi semaksimal mungkin contohnya dengan cara pemasangan poster di tempat umum atau pembuatan video-video edukasi yang dapat diposting di sosial media seperti youtube, instagram, maupun televisi.

\section{DAFTAR PUSTAKA}

Allo, O. (2015). Hubungan pengetahuan keluarga tentang penyakit stroke dengan dukungan keluarga dalam merawat pasien stroke di ruang rawat interna RSUD Laki-Laki pada tahun 2015. Jurnal AgroSainT, VI, 156-163.

Anand, L., Sumeet, S., \& George, R. (2017). Effectiveness of education programme on knowledge among caregivers of stroke patients. International Journal of Nursing Education, 9(6), 6-11.

Haghighi, B. A, Karimi. A. A., Amiri, A., \& Ghaffarpasand, F. (2010). Knowledge and attitude towards stroke risk factors, warning symptoms and treatment in an Iranian population. Medical Principle and Practice, 19(6), 468472. doi: $10.1159 / 000320306$

Cheng, H., Chair, S., \& Chau, J. (2018). Effectiveness of a strength-oriented psychoeducation on caregiving competence, problem-solving abilities, psychosocial outcomes and physical health among family caregiver of stroke survivors: A randomised controlled trial. International Journal of Nursing Studies, 87, 84-93.

Das, K., Mondal, G., Dutta, A., \& Mukherjee, B. (2010). Awareness of warning symptoms and risk factors of stroke in the general population and in survivors stroke. Jurnal of Clinical Neuroscience, 14(1), 12-16. doi: 10.1016/j.jocn.2005.12.049.

Egerton, T., Hokstad. A., Askim, T., Bernhardt, J., \& Indredavik, B. (2015). Prevalence of fatigue in 
patients 3 months after stroke and association with early motor activity: A prospective study comparing stroke patients with a matched general population cohort. BMC Neurology, 15(181), 1-9. doi: 10.1186/s12883-015-0438-6

Febriani, N., Handiyani, H., \& Kuntarti. (2019). Pentingnya persiapan dalam pendidikan kesehatan pada Pasien di Rumah Sakit. Universitas Indonesia.

Handayani, F., \& Pudjonarko, D. (2015). Associated factor and predictor of post stroke depression after 3 month onset. Java International Nurse Conference, 170-177. Diambil dari https://core.ac.uk/download/pdf/76 930906.pdf

Hokmabadi, E., Vahdati, S., \& Rikhtegar, R. (2017). Public knowledge about stroke. Emergency Medicine, 7(1), 1-2. doi: 10.4172/21657548.1000344

Kementerian Kesehatan Republik Indonesia (2018). Hasil utama riset kesehatan dasar. Diperoleh dari https://www.kemkes.go.id/resource s/download/info-terkini/hasilriskesdas-2018.pdf

Kosasih, C., Solehati, T., \& Isabela, P. (2018). Pengaruh edukasi kesehatan terhadap pengetahuan pasien stroke dan keluarga: Peran, dukungan, dan persiapan perawatan pasien stroke di rumah. Media Kesehatan Politeknik Kesehatan Makassar, 13(2), 8-13.

Lailatun, N., Nurwahyuni, T., \& Wahyuni, E. (2018). Pengaruh pendidikan kesehatan media booklet terhadap pengetahuan dan sikap keluarga tentang speech therapy pada pasien stroke di IRNA Seruni A RSUD Dr. Soetomo Surabaya. Jurnal Ners Lentera, 6, 78-88.

Pandian J. D., Jaison, A., Deepak, S. S., Kalra, G., Shamsher, S., Lincoln, D., J. ... Abraham, G. (2015). Public awareness of warning symptoms, risk factors, and treatment of stroke in Northwest India. Stroke, 36(3), 644-648. doi: 10.1161/01/STR.0000154876.0846 8. $\mathrm{a} 0$

Pandit, R., Mathews, M., \& Sangle, S. (2017). Caring for stroke Patients: caregivers' knowledge and practices. International Journal of Recent Scientific Research, 8(6), 17563-6. doi: 10.24327/ijrsr.2017.0806.0380

Pothiban, L., Khampolsiri, T., \& Srirat, C. (2018). Knowledge and awareness of stroke impacts among Northern Thai population. Pacific Rim International Journal of Nursing Research, 22(3), 212-222.

Rachmawati, D., Ningsih, D., \& Andarini, S. (2020). Factors affecting the knowledge about stroke risks and early symptoms in emergency pepartment East Java-Indonesia. Malang Neurology Journal, 6(1), 10-18. doi: 10.21776/ub/mnj.2020.006.01.3

Rajegowda, S., Pinto, V., \& George, P. (2017). Study on stroke awareness among caregivers of stroke patients. International Journal of Biomedical Research, 8(8), 848847. 
Riduan D. A. (2018). Pengaruh edukasi deteksi dini stroke dengan metode audiovisual terhadap tingkat pengetahuan dan sikap individu dengan risiko tinggi stroke di Wilayah Kerja Puskesmas Perumnas II Kota Pontianak. Universitas Tanjungpura.

Safitri, F. N. (2012). Resiko stroke berulang dan hubungannya dengan pengetahuan dan sikap keluarga. Students e-Journals, 1(1), 1-13.

Saad, S., Waqar, Z., Islam, F., Iqbal, H., \& Nomani, A. (2017). The awareness of stroke in caregivers of stroke patients in Pakistan. Journal of Neurological Disorders, (4)5, 1-4. doi: 10.4172/2329-6895.1000359

Schneider, A. T., Pancioli, A. M., Khoury, J. C., Rademacher, E. Tuchfarber, E., Miller, R. ... Broderic, J. P. (2011). Trends in community knowledge of the warning signs and risk factors for stroke. Journal of America Medical Association, (289)3, 343-346. doi: 10.1001/jama.289.3.343

Semet, G., Kembuan, M., \& Kerema, W. (2016). Gambaran pengetahuan stroke pada penderita dan keluarga. Journal e-Clinic, 4, 4-9.

Simandalahi, T. (2017). Analisis hubungan tingkat pengetahuan dan sikap keluarga dengan kemampuan keluarga merawat pasien pasca stroke. Jurnal Kesehatan Medika Saintika, 9(1), 41-48.

Singh, C., \& Sandeepkumar, N. (2019). Evaluate the effectiveness of Information Booklet on knowledge regarding stroke rehabilitation among caregivers of stroke patients. Journal of Nursing and Health Science, 8, 6-10. doi: 10.9790/1959-0804080610

Subri, M. (2003). Ekonomi sumber daya manusia. Jakarta: Raja Grafindo.

Sukron, \& Phutthikhamin, N. (2016). The development of caregivers knowledge about stroke and stroke caregiving skills tools for stroke caregivers in Indonesia. International Journal of Health Life-Sciences, 2(2), 35-47.

Wardhani, N., \& Martini, S. (2014). Faktor yang berhubungan dengan pengetahuan tentang stroke pada pekerja institusi pendidikan tinggi. Jurnal Berkala Epidemiologi, 2(1), 13-23.

World Health Organization. (2014). Stroke cerebrovascular accident. Diperoleh dari http://www.who.int/topics/ cerebrovascular_accident/en/

Zeng, Y., He, G., Yi, G., Huang, Y., Zhang, Q., \& He, L. (2012). Knowledge of stroke warning signs and risk factors among patients with previous stroke or TIA in China. Journal of Clinical Nursing, 21, 2886-95. doi: 10.1111/j.13652702.2012.04118.x. 
Volume 3, No. 2, November 2020 (Hal. 38-49)

Available Online at https://ejournal2.undip.ac.id/index.php/hnhs

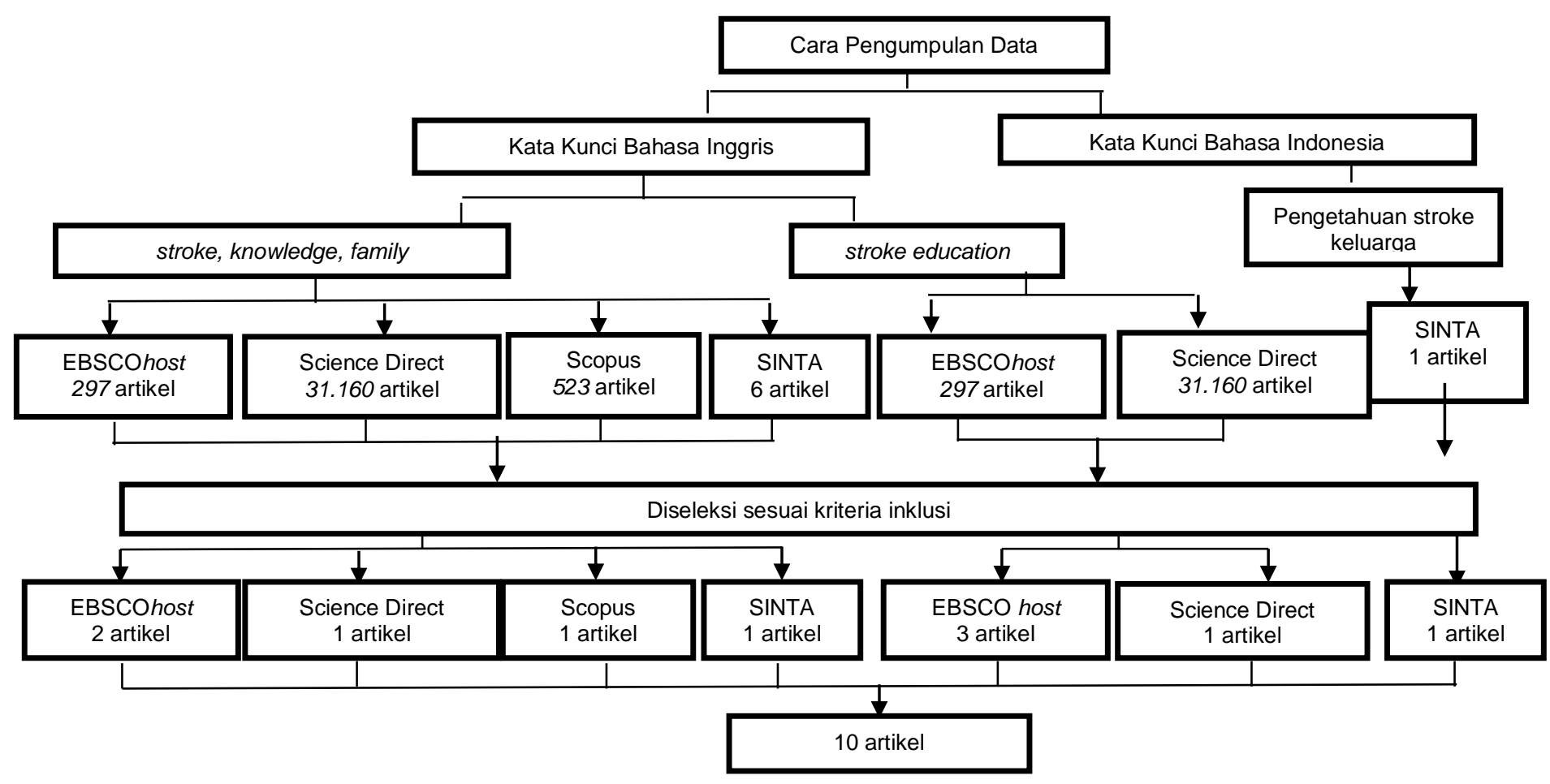

Gambar 1. Bagan Alur Pengumpulan Data 
Tabel 1. Matriks Sintesis

\begin{tabular}{|c|c|c|c|c|c|}
\hline No & $\begin{array}{l}\text { Penulis } \\
\text { /Tahun }\end{array}$ & Judul Artikel & $\begin{array}{c}\text { Metode } \\
\text { Penelitian }\end{array}$ & $\begin{array}{c}\text { Karakteristik } \\
\text { Responden }\end{array}$ & Temuan Penelitian \\
\hline 1. & $\begin{array}{l}\text { Anand } \\
\text { L, } \\
\text { Sandhy } \\
\text { a } \\
\text { Sumeet } \\
\text {, Rosy } \\
\text { george } \\
(2017)\end{array}$ & $\begin{array}{l}\text { Effectiveness } \\
\text { Education } \\
\text { Programme } \\
\text { Knowledge among } \\
\text { Caregivers of Stroke } \\
\text { Patients }\end{array}$ & $\begin{array}{l}\text { Quasi } \\
\text { experimental } \\
\text { one group } \\
\text { pre-test dan } \\
\text { post-test } \\
\text { design }\end{array}$ & $\begin{array}{ll}\text { a. } & \text { Usia } \\
& \text { Dibawah } \\
\text { tahun : } 7 \\
\text { Diatas } 30 \text { tahun } \\
: 13 \\
\text { b. } \\
\text { Pendidikan } \\
\text { Buta huruf : } 5 \\
\text { Terpelajar : } 15\end{array}$ & $\begin{array}{l}\text { Dari } 20 \text { caregiver didapatkan hasil: } \\
\text { a. Caregiver dengan usia dibawah } 30 \\
\text { tahun } 6 \text { orang memiliki pengetahuan } \\
\text { yang baik dan } 1 \text { orang berpengetahuan } \\
\text { kurang } \\
\text { b. Caregiver dengan usia di atas } 30 \text { tahun } \\
6 \text { orang berpengetahuan baik dan } 7 \\
\text { orang berpengetahuan kurang } \\
\text { c. Caregiver laki-laki } 4 \text { berpengetahuan } \\
\text { baik dan } 3 \text { berpengetahuan kurang } \\
\text { d. Caregiver perempuan } \\
\text { berpengetahuan baik dan } \\
\text { berpengetahuan kurang } \\
\text { e. Caregiver berpendidikan } 12 \text { orang } \\
\text { berpengetahuan baik dan } \\
\text { berpengetahuan kurang } \\
\text { f. Caregiver yang kurang berpendidikan } \\
\text { seluruhnyayaitu } \\
\text { berpengetahuan buruk } 5 \\
\text { g. Hasil keseluruhan pengetahuan } \\
\text { keluarga masih buruk (Anand, Sumeet, } \\
\text { \& George, 2017). }\end{array}$ \\
\hline
\end{tabular}

2. Dewi Factors Affecting Cross

Rachm Knowledge Towards sectional

awati, Stroke Risks and design

Dewi Early Symptoms

K.

Ningsih

, Sri

Andari

ni

(2020)

3. Sanjana

Tallihal

la

Rajego

wda,

Veena

Jasmine

Pinto,

dan

Peter

George

(2017)

$\begin{array}{llrl}\mathrm{ng} & \text { Awareness of Stroke } & \text { sectional } \\ \text { Pothiba } & \text { Impacts } & \text { Among } & \text { design } \\ \mathrm{n}, & \text { Northern } & \text { Thai }\end{array}$

a. Usia

<40 tahun: 16

40-60 tahun: 37

$>60$ tahun: 5

b. Pendidikan

SD : 27

SMP : 13

SMA : 12

Sarjana: 6

a. Usia

18-40 tahun: 19

(38\%)

41-60 tahun: 21

(42\%)

61-80 tahun: 10

(20\%)

b. Pendidikan

Tidak

berpendidikan :

20\% SMP: $34 \%$

SMA: $\quad 24 \%$

Sarjana: $22 \%$

a. Usia

$<20$ tahun: $11 \%$

20-59 tahun:

$73 \%$
Penelitian ini menunjukkan bahwa ratarata pengetahuan responden tentang faktor risiko stroke adalah 4,02 $\pm \mathrm{SD}$ 2,172, sebanyak $63,8 \%$ responden memiliki skor pengetahuan di bawah rata-rata $(<4,02)$, menunjukkan bahwa mayoritas responden memiliki pengetahuan yang kurang mengenai faktor risiko stroke sementara sisanya $36,2 \%$ memiliki pengetahuan yang baik (Rachmawati, Ningsih, \& Andarini, 2020).

Family caregiver dalam penelian ini mayoritas memiliki tingkat pengetahuan yang baik mengenai tanda gejala dan faktor resiko stroke sebesar $74 \%$ sementara sisanya $26 \%$ berpengetahuan buruk (Rajegowda, Pinto, \& George, 2017)

Tingkat pengetahuan dalam penelitian ini dibagi menjadi tiga kategori yaitu low,moderate dan high. Hasil pengetahuan keluarga dalam penelitian 
Totsapo Population

rn

Khamp

olsiri,

Chomp

hoonut

Srirat

(2018)

5. Sukron

dan

Phutthi

The Development of Caregivers

khamin

Knowledge About

(2016) Caregiving Skills

Tools for Stroke

Caregivers in

Indonesia

6. Rahul Caring For Stroke

B. Patients: Caregivers,

Pandit, Knowledge and

Mary Practices

Mathe

ws dan

Shashik

ala

Sangle

(2017)

7. Giovan Gambaran

ni R. pengetahuan stroke

Semet, pada penderita dan

Mieke keluarga di RSUP

A. H. Prof. Dr. R. D

N. Kandou Manado

Kembu

an,

Winifre

d

Karema

(2016)

8. Ho Yu Effectiveness of $a$

Cheng, strength-oriented

Sek

Ying

Chair, psychoeducation on

caregiving

Janita problem-solving

Pak abilities,

Chun psychosocial

Chau outcomes and

(2018) physical health

among family

caregiver of stroke

survivors

9. Saira The Awareness of

Saad, Stroke in Caregivers

Zaid of Stroke Patients in

Waqar, Pakistan

Fasihul
$>59$ tahun: $16 \%$

b. Pendidikan

Tidak

berpendidikan :

19\% SMP: $30 \%$

SMA: $\quad 28 \%$

Sarjana: $23 \%$

Descriptive study

a. Usia

18-30 tahun: 11

31-60 tahun: 15

$>60$ tahun: 4

descriptive

research

a. Usia

21-30 tahun: 15

31-40 tahun: 34

41-50 tahun: 26

51-60 tahun: 25

b. Pendidikan

Buta huruf: 26

SD : 18

SMP: 26

SMA: 13

Sarjana: 17

Descriptive

survey

a. Usia

15-25 tahun: 9

26-45 tahun: 8

46-65 tahun: 10

b. Pendidikan

SMA/SM: 18

D3: 2

S1: 7

A prospective a. Usia multi-centre and singleblinded randomised controlled trial cross-

design sectional a. Usia

Usia responde

36-57 tahun

b. Pendidikan onden

kurang dari 12

tahun ini pada kategori low knowledge sebesar $13 \%$, moderate knowledge sebesar $29 \%$ dan mayoritas hasil pada penelitian ini termasuk dalam kategori high knowledge yaitu sebesar 58\% (Pothiban, Khampolsiri, \& Srirat, 2018).

Hasil pengetahuan keluarga sebagai caregiver dalam merawat pasien stroke pada penelitian ini mayoritas termasuk dalam kategori yang baik sebesar $60 \%$ (18 responden) dan 40\% (12 responden) masuk dalam kategori buruk (Sukron \& Phutthikhamin, 2016).

Responden dalam penelitian ini mayoritas memiliki pengetahun dan praktik perawatan yang buruk sebesar $78 \%$ dan sisanya berpengetahuan baik sebesar 12\% (Pandit, Mathews, \& Sangle, 2017).

Hasil penelitian menyatakan bahwa responden yang terdiri dari 19 pasien dan 27 keluarga pasien memiliki tingkat pengetahuan yang tinggi mengenai stroke dan pengetahuan pasien stroke lebih tinggi dari pada keluarganya (Semet, Kembuan, \& Kerema, 2016).

Responden yang tidak mendapatkan edukasi keseluruhannya tergolong dalam pengetahuan yang buruk disertai dengan hasil perawatan yang tidak optimal (Cheng, Chair, \& Chau, 2018).

Hasil penelitian ini menyatakan bahwa pengetahuan family caregiver $89 \%$ memiliki pengetahuan buruk dan $11 \%$ yang tergolong kategori pengetahuan baik (Saad, Waqar, Islam, Iqbal, \& 
Volume 3, No. 2, November 2020 (Hal. 38-49)

Available Online at https://ejournal2.undip.ac.id/index.php/hnhs

Islam ,

Humair

a Iqbal

and Ali

Zohair

Nomani

(2017)

10. Chandr apal

Singh,

Sandee

pkumar

$\mathrm{N}$.

(2019)

Evaluaterthe Aquantitative
effectiveness of experimental
Information Booklet study
on knowledge
regarding stroke
rehabilitation among
caregivers of stroke
patients

Buta Huruf: $32 \quad$ Nomani, 2017).

SD : 43

SMP: 8

SMA: 14

Sarjana: 3

a. Usia

Rentang usia responden 18-

50 tahun

b. Pendidikan

SD: 22

SMP: 18

SMA: 17

Sarjana: 3
Tingkat pengetahuan family caregiver pada saat pretest adalah kurang baik yaitu 11.9 (37.18\%) dan meningkat setelah mendapatkan intervensi pemberian booklet menjadi 26.98 $(84.31 \%)$ (Singh \& Sandeepkumar, 2019). 